
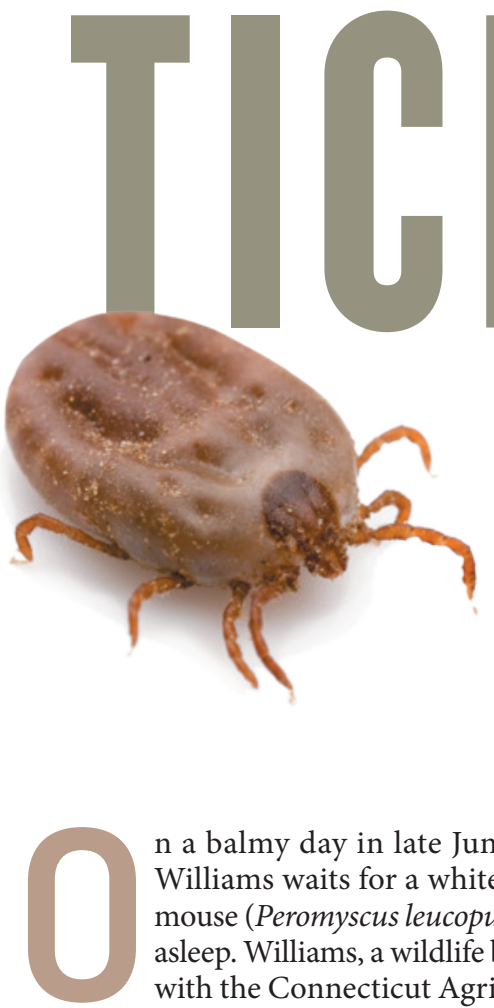

n a balmy day in late June, Scott Williams waits for a white-footed mouse (Peromyscus leucopus) to fall asleep. Williams, a wildlife biologist with the Connecticut Agricultural Experiment Station in New Haven, has just transferred the animal from a trap to a plastic bag containing a cotton ball doused in anaesthetic. As soon as the mouse's breathing slows to one breath per second, Williams will take it out, draw blood, weigh it, put an ear tag on it for identification and check the animal for ticks, saving any that are engorged with blood. He must work quickly. The mouse will wake up in about two minutes, and she might be grumpy.

Williams is testing whether vaccinating mice against Borrelia burgdorferi, the bacterium that causes Lyme disease in the United States, can reduce the proportion of ticks that are infected. Health officials are looking on with interest. Connecticut has one of the highest rates of human Lyme disease in the country, and June is peak time for transmission. Borrelia burgdorferi infects an estimated 329,000 people in the United States each year, according to the US Centers for Disease Control and Prevention (CDC) in Atlanta, Georgia. And although most people who get prompt treatment recover quickly — Williams has had Lyme three times - up to one in five develops long-term and potentially life-threatening symptoms, including heart, vision or memory problems, or debilitating joint pain.

Williams's approach is one of several strategies being tested in an attempt to thwart the spread of tick-borne diseases. Some, like the mouse vaccine, interrupt the pathogen's ecological circuitry by targeting the wild animals that pass along and amplify the disease. Others, such as efforts to revive a human Lyme vaccine,

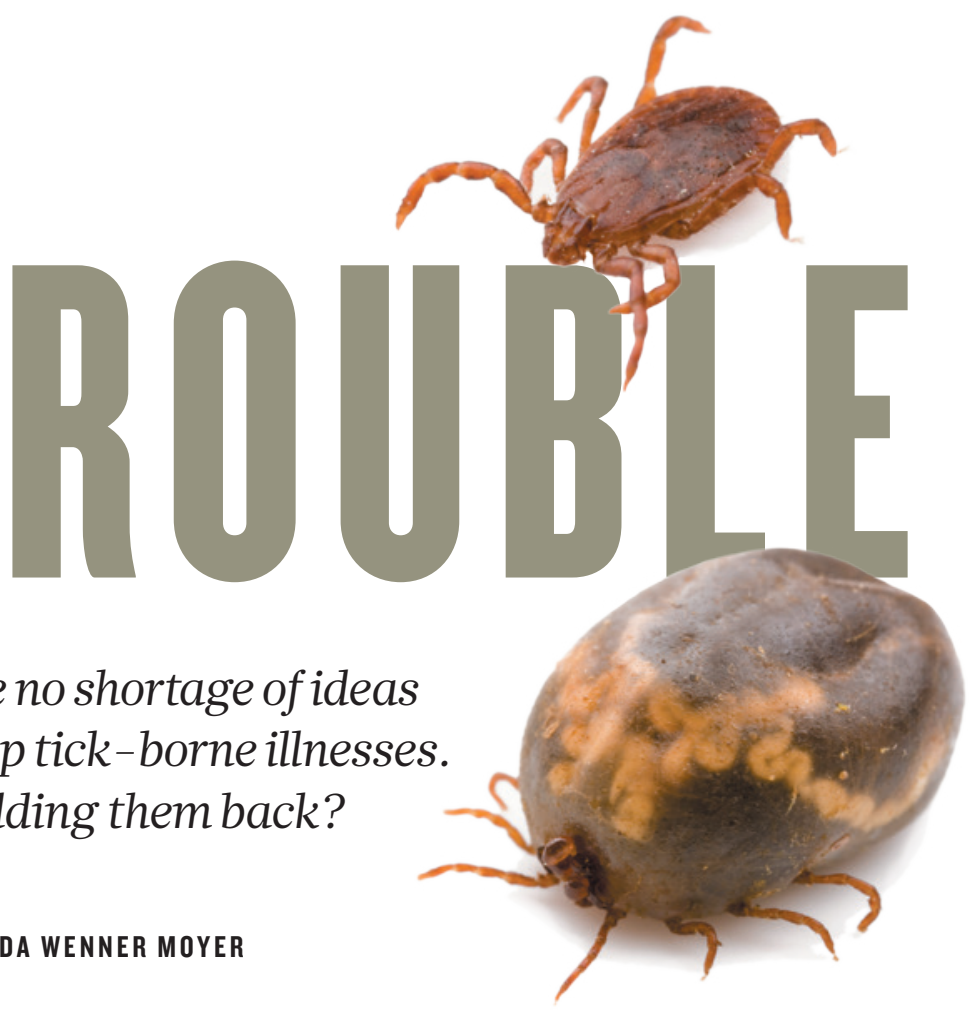

aim to protect people from infection directly. A more radical approach could hamper the ability of ticks to bite humans or animals, potentially protecting against dozens of illnesses spreading across the United States, Europe, Africa and Asia.

That the field needs creative solutions is clear. Many long-recommended interventions, such as pesticide application or controlling populations of deer, which are an important host for adult ticks, have had mixed success in scientific studies. Even the time-honoured protective strategies that most people use are not evidence-based. "We tell people to wear repellents, to do tick checks and to shower if they've been in the field, but there's very little data to show that these things reduce human illness," explains Ben Beard, chief of the CDC's bacterial-diseases branch in the division of vector-borne diseases.

Diseases spread by ticks are on the rise around the world, spurred by a combination of factors, including shifting climates and population sprawl into rural areas. Reported cases of Lyme, the most common US tick-borne illness, have nearly tripled in the country since 1992, although some of the increase could be due to heightened awareness. Lyme is also a growing problem in parts of Europe, Mongolia and China. Yet as bad as it is, there are nastier threats on the rise. In parts of Africa, the Middle East, Asia and southern Europe, ticks can spread Crimean-Congo haemorrhagic fever, which is fatal in $40 \%$ of cases. And a tick-borne relapsing fever afflicts as many as 1 in 20 residents in parts of Senegal. In the United States, ticks spread at least 16 illnesses, including anaplasmosis, babesiosis, ehrlichiosis and Rocky Mountain spotted fever, all "serious, life-threatening infections", Beard says. And many are increasing in incidence more quickly than Lyme. In a July 2015 position statement, the Entomological Society of America argued for a national strategy to combat tick-borne diseases. "The recent confluence of environmental, ecological, sociological, and human demographic factors," it said, "has created a near 'perfect storm' leading to more ticks in more places throughout North America”"

\section{BACKYARD BATTLEGROUNDS}

Williams tags, weighs and releases his mouse just in time. It has no ticks to bring back to the lab for further analysis, but there will be other opportunities. Members of 32 Connecticut households have volunteered to place traps around their properties, and some will also get boxes of mouse treats laden with vaccine. The hope is that, over time, fewer mice and ticks will harbour the bacteria at the sites with the vaccine bait.

The plan is unconventional, because most Lyme-control measures focus on white-tailed deer (Odocoileus virginianus), which have exploded in number in the United States over the past century as young forests have become increasingly fragmented by human development and large predators have been all but eradicated. Adult blacklegged ticks (Ixodes scapularis) typically feed and mate on deer, so many scientists have argued that the only way to get rid of Lyme is to get rid of the deer.

But such efforts have had "an incredibly spotty record", says Richard Ostfeld, a disease ecologist at the Cary Institute of Ecosystem Studies in Millbrook, New York, who has been studying tick-borne diseases for decades.

When Sam Telford, an epidemiologist at Tufts University in North Grafton, Massachusetts, and his colleagues cut the deer population on 
The body of an adult ixodid tick expands as it feeds.

Great Island in Cape Cod by $50 \%$ in the early 1980s, they saw no drop in tick numbers - the number of tick larvae on the island actually increased ${ }^{1}$. Ostfeld argues that you do not need many deer to maintain a large tick population. When deer numbers drop, ticks can either crowd in on the remaining deer or find other hosts. Only when almost all of the deer on Great Island had been eliminated did tick populations plummet. But, says Telford, "it is a nightmare trying to get the deer population down that low". And anywhere that is not an island, keeping populations down is practically impossible.

\section{DANGERMOUSE}

Ostfeld and others contend that mice are a major driver for both the tick problem and the disease problem. Mice, like deer, flourish in fragmented woodlands - in part because predators such as foxes and opossums get displaced. Ticks then thrive on the rodents, which are poor groomers. Studies suggest that larval ticks have a $50 \%$ chance of surviving when they feed on mice, but only a $3.5 \%$ chance on opossums ${ }^{2}$.

And mice are typically where ticks pick up B. burgdorferi. Most mice in Lyme-endemic areas get infected with the bacterium at a young age and, for reasons that are not completely clear, they are particularly good at transmitting it to ticks. Almost all young ticks that feed on white-footed mice become infected, compared with a mere $1 \%$ of ticks that feed on deer. Interrupting the tick-mouse infection cycle, says Ostfeld, could make ticks a lot less dangerous.

Maria Gomes-Solecki, a medical microbiologist at the University of Tennessee Health Science Center in Memphis, agrees - which is why she invented the mouse vaccine that Williams is testing. It primes the mice to make antibodies against outer surface protein A (OspA), a molecule that B. burgdorferi expresses when it is in a tick's gut. A mouse eats the vaccine, then starts to produce OspA antibodies. The next time a tick feeds on the mouse, the antibodies attack the bacteria in its gut, clearing the infection. As the proportion of ticks infected with $B$. burgdorferi drops, it becomes less likely that the next generation of mice will pick up the parasite, even without vaccination.

Ostfeld and his colleagues reported the first field tests ${ }^{3}$ of Gomes-Solecki's vaccine in 2014, and found that although only $28 \%$ of the mice in an area that they targeted for 5 years developed protective levels of OspA antibodies, the prevalence of infected blacklegged-tick nymphs (the life stage between larvae and adults) dropped by $75 \%$. The bait-based vaccine is also attractive because it is less ecologically destructive than other strategies - it does not kill animals or even ticks, just the pathogens.

Gomes-Solecki, who licensed her technology to a company she founded, US Biologic in Memphis, would like to see homeowners putting walk-through bait boxes for mice governments could disperse the bait in parks or forests, much as they do with bait-based rabies vaccines for raccoons and coyotes. "The rodents seem to love them," Williams says of the vaccine-laced treats. One of his colleagues calls them "Fritos for mice".

\section{"WE'VE DISRUPTED THE BALANCE OF NATURE:"}

Other scientists argue for more a direct means of protecting people against Lyme, ideally with a human vaccine. When vaccine researcher Stanley Plotkin's son was 35, he fell ill with Lyme disease. As often happens with the infection, a doctor missed the diagnosis and the young man went untreated for months. Bacteria invaded his heart and he collapsed one day while walking his dog. Plotkin, now an emeritus professor at the University of Pennsylvania in Philadelphia, says that when paramedics arrived, his son's heart rate was dangerously low. He has since recovered, but the experience "further convinced me, if I needed any convincing", Plotkin says, "that the lack of a Lymedisease vaccine was a public-health tragedy".

Plotkin worked on a vaccine in the 1990s. Ultimately, a competing product called around their gardens. Or, she says, local

LYMErix, manufactured by UK-based pharmaceutical company SmithKline Beecham (now GlaxoSmithKline), was approved by the US Food and Drug Administration in 1998. It reduced the risk of Lyme caused by US strains of Borrelia by $76 \%$ in clinical trials ${ }^{4}$. But it faced problems from the start. First, it garnered lukewarm support from health officials in the United States and was recommended only for people aged 15 to 70 in regions where Lyme is endemic. Then, some recipients complained of autoimmune-related side effects such as arthritis and filed lawsuits against SmithKline Beecham. The company voluntarily shelved LYMErix in 2002. Plotkin maintains that this was a mistake. "The vaccine was safe," he says.

Now, a new and potentially improved vaccine has completed safety trials ${ }^{5}$. Developed by researchers at Stony Brook University and Brookhaven National Laboratory in New York, and licensed to Baxter Innovations in Vienna, the vaccine is similar to LYMErix in that it targets OspA, but it does not contain the protein segment that some scientists and consumers feared could cause an autoimmune reaction. It also contains several variants of OspA, so it protects against many Borrelia species known to cause Lyme in humans, including those that affect people in Europe.

Nevertheless, the vaccine's future is uncertain: in 2014, Pfizer bought the rights to sell many of Baxter's vaccine products, but not the Lyme candidate. Baxter is now in talks with Great Plains Biotechnology of Roca, Nebraska, which has expressed interest in purchasing and developing the Lyme vaccine.

Richard Marconi, a microbiologist and vaccinologist at Virginia Commonwealth

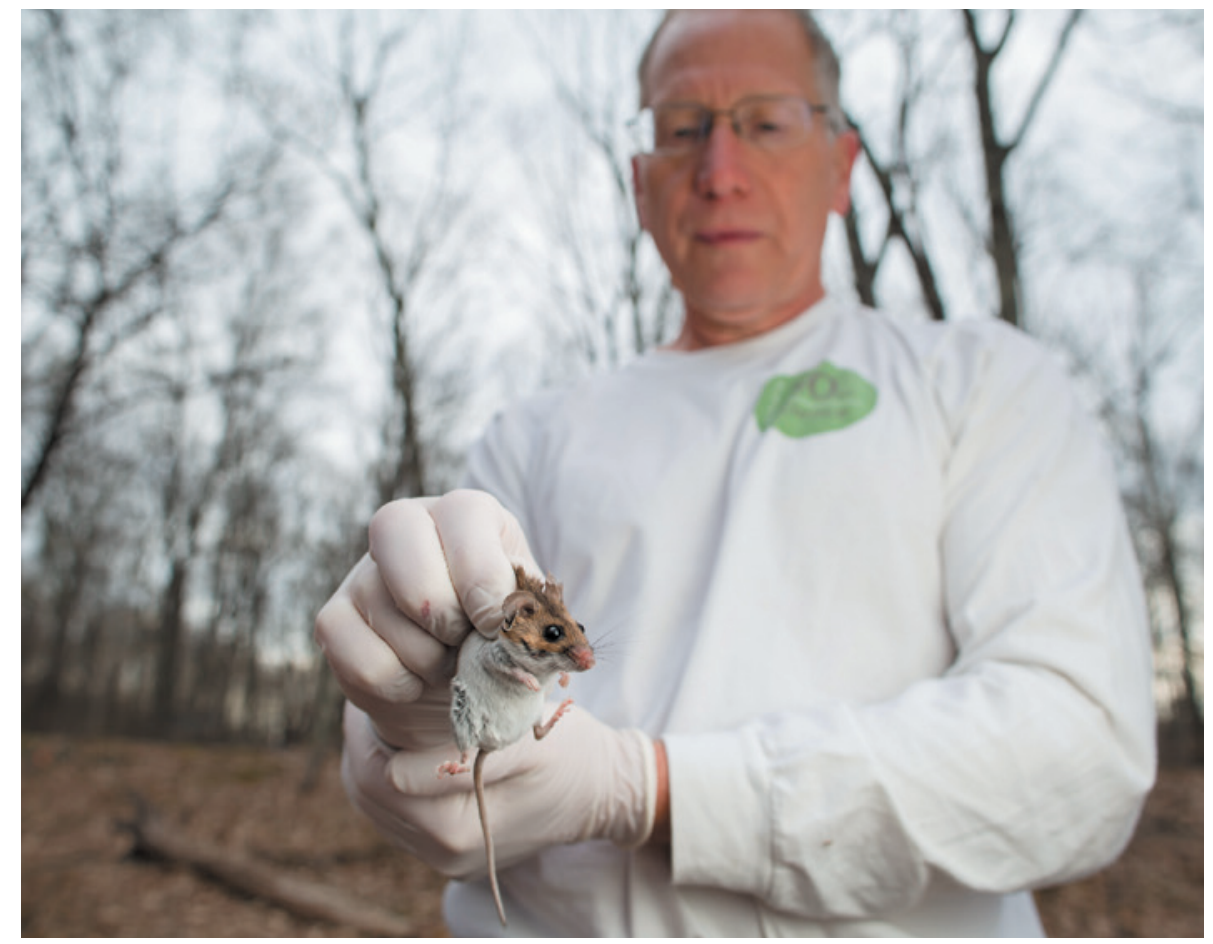

Disease ecologist Rick Ostfeld says that Lyme disease should be tackled in part by targeting mice. 
REALITY BITES Not just an affliction of affluent New Englanders, tick-borne illnesses pose a threat to public health around the world. And they seem to be on the rise.

\section{DISEASE}

$>100,000$ NEW CASES EACH YEAR

\begin{tabular}{|c|c|c|}
\hline $\begin{array}{l}\text { Lyme disease } \\
\text { Borrelia burgdorferi and } \\
\text { other Borrelia bacteria }\end{array}$ & $\begin{array}{l}\text { Blacklegged tick } \\
\text { (Ixodes scapularis) and } \\
\text { other Ixodes species }\end{array}$ & Global \\
\hline \multicolumn{3}{|l|}{ 10,000-100,000 NEW CASES EACH YEAR } \\
\hline $\begin{array}{l}\text { Tick-borne encephalitis (including } \\
\text { Powassan and deer-tick virus) } \\
\text { Flavivirus species }\end{array}$ & $\begin{array}{l}\text { Various Ixodes } \\
\text { species }\end{array}$ & $\begin{array}{l}\text { North America, } \\
\text { Europe, Russia, } \\
\text { China, Mongolia }\end{array}$ \\
\hline $\begin{array}{l}\text { Spotted fevers (including } \\
\text { Rocky Mountain spotted fever) } \\
\text { Rickettsia bacteria }\end{array}$ & $\begin{array}{l}\text { American dog tick } \\
(\text { Dermacentor } \\
\text { variabilis) and others }\end{array}$ & Global \\
\hline \multicolumn{3}{|l|}{ 1,000-10,000 NEW CASES EACH YEAR } \\
\hline $\begin{array}{l}\text { Babesiosis } \\
\text { The protozoan Babesia microti } \\
\text { and other Babesia species }\end{array}$ & $\begin{array}{l}\text { Various /xodes } \\
\text { species }\end{array}$ & $\begin{array}{l}\text { The Americas, } \\
\text { Europe, southern } \\
\text { and eastern Asia }\end{array}$ \\
\hline $\begin{array}{l}\text { Tick-borne relapsing fever } \\
\text { Borrelia miyamotoi and other } \\
\text { Borrelia species }\end{array}$ & $\begin{array}{l}\text { Soft-bodied ticks of th } \\
\text { genus Ornithodoros, } \\
\text { and Ixodes species }\end{array}$ & $\begin{array}{r}\text { The Americas, } \\
\text { Europe, Asia, } \\
\text { Africa }\end{array}$ \\
\hline $\begin{array}{l}\text { Ehrlichiosis and anaplasmosis } \\
\text { Ehrlichia and Anaplasma } \\
\text { bacteria }\end{array}$ & $\begin{array}{l}\text { Lone star tick } \\
\text { (Amblyomma americ } \\
\text { and Ixodes species }\end{array}$ & Global \\
\hline \multicolumn{3}{|l|}{ 100-1,000 NEW CASES EACH YEAR } \\
\hline $\begin{array}{l}\text { Tick-borne tularaemia } \\
\text { Francisella tularensis bacterium }\end{array}$ & $\begin{array}{l}\text { Ticks of the } \\
\text { genus Dermacentor } \\
\text { and Amblyomma }\end{array}$ & $\begin{array}{l}\text { astern and central } \\
\text { ited States, central } \\
\text { Europe, Russia }\end{array}$ \\
\hline
\end{tabular}

University in Richmond, says that he and his colleagues are working on an even better vaccine. One downside of an OspA vaccine is that it requires frequent boosters, because OspA antibodies have to be circulating constantly in the blood if they are to attack B. burgdorferi inside a biting tick. Marconi's team is developing a vaccine against immunologically relevant portions of the surface protein $\mathrm{OspC}$, which B. burgdorferi expresses when it is inside mammals. On being bitten by infected ticks, vaccinated individuals can produce OspC antibodies from immunological memory; the antibodies do not have to be circulating already. Marconi and his colleagues have already licensed a version of the vaccine for use in dogs, and "the success of the canine vaccine and the uniqueness of the approach suggests that it's going to be highly effective in humans", he says.

In light of the problems faced by LYMErix, however, the question remains whether health officials and consumers will embrace a human vaccine. "I think, maybe optimistically, that the emotional situation has changed over the last 10 or 15 years - that is, that more people are convinced of the importance of Lyme disease," Plotkin says. But it is hard to know whether fears about Lyme will trump fears about the vaccine.

Mouse vaccines would not raise such concerns, but some researchers, including Plotkin, are sceptical about whether they could dose enough mice to reduce Lyme rates. And both vaccine approaches are limited because they combat only one tick-borne disease, when more than a dozen others are spreading throughout the world (see 'Reality bites').

\section{TICK SPIT}

There is one strategy that could conquer them all, and it involves turning one of the tick's most ingenious tools - its saliva - against it. When a tick bites a host, molecules in its saliva help it to evade detection and start to feed by blocking pain, inflammation and immune signals. If a vaccine could raise an immune response to key salivary proteins, it could make tick bites more noticeable or block the tick's ability to feed.

Ostfeld himself is a proof-of-concept for this approach. He has been bitten more than 100 times, and his body now reacts to tick saliva. "I realize when a tick is biting me because I get a burning sensation. It's pretty intense," he explains. Ostfeld has ample time to remove the even survives the experience. Often, Ostfeld says, he will remove a tick only to discover that, for unknown reasons, it is already dead.

A European Commission-funded consortium called ANTIDotE (Anti-tick Vaccines to Prevent Tick-borne Diseases in Europe) is characterizing the tick salivary proteins that could be targeted to thwart feeding. In 2011, a member of the group reported ${ }^{6}$ a technique to rapidly identify those proteins that react with the blood serum of tick-immune animals. When the team vaccinated rabbits against three salivary tick before it can transfer an infection - if it proteins that it had identified - including one that ticks use to inhibit blood coagulation and one that inhibits the host's immune response — it found that ticks had trouble getting blood from them. Researchers in the group are also working to identify the salivary genes involved in B. burgdorferi transmission. "We think that an anti-tick vaccine could be immensely useful in protecting both humans and animals," says Hein Sprong, an ANTIDotE leader at the National Institute for Public Health and the Environment in Bilthoven, the Netherlands.

US Biologic also plans to develop a baitbased vaccine for mice that could thwart tick feeding, thereby protecting against multiple diseases. That could reduce overall tick numbers, too, because it would make it difficult for larval ticks to get the meals that they need to survive into adulthood and reproduce.

But these approaches are hardly around the corner. Part of the problem, scientists say, is that funding is scarce. The stereotype of Lyme and other US tick-borne diseases as primarily 'yuppie' illnesses does not help; Ostfeld says he has seen comments to this effect on reviews of his grant proposals. "They say something like, 'Is it really worth spending taxpayer dollars on a disease of the affluent in the northeastern United States, when there are so many diseases of people who live in poverty overseas?'”' he says. "In one sense, I think that's a legitimate point, but in another, I think it underestimates the impact of this disease on a vast number of citizens, not all of whom are affluent, not even close." Another potential reason for low funding is that in the United States Lyme and similar infections are only rarely fatal. Each year, more people in the United States are diagnosed with Lyme than with prostate cancer, but research funding for the latter from the National Institutes of Health was more than ten times that for Lyme in 2014.

Until an all-encompassing solution becomes available, controlling tick-borne diseases will probably require an array of smaller-scale approaches that attack the problem, bit by bit, on a number of levels. That an arsenal of such weapons might be needed to hold back the enemy is not particularly surprising, considering the complexity of tick-borne-disease ecology, how drastically humans have been changing it, and how close people live to these disease-carrying parasites. "We've disrupted the balance of nature," Telford says. Steadying the scales again will be no small feat.

Melinda Wenner Moyer is a freelance science writer in Cold Spring, New York.

1. Wilson, M. L., Telford, S. R. III, Piesman, J. \& Spielman, A. J. Med. Entomol. 25, 224-228 (1988).

2. Keesing, F. et al. Proc. R. Soc. B 276, 3911-3919 (2009).

3. Richer, L. M. et al. J. Infect. Dis. 209, 1972-1980 (2014).

4. Steere, A. C. et al. N. Engl. J. Med. 339, 209-215 (1998).

5. Wressnigg, N. et al. Lancet Infect. Dis. 13, 680-689 (2013).

6. Schuijt, T. J. et al. PLoS ONE 6, e15926 (2011). 